\title{
A hoard of flint items from Verbicioara, Romania
}

\author{
Cristian E. Ştefan \\ Vasile Pârvan Institute of Archaeology, Romanian Academy, Bucharest, RO \\ cristarh_1978@yahoo.com
}

\begin{abstract}
Specialists have always been interested in object depositions from prehistoric settlements. Such depositions have been analysed in relation to their respective contexts, structures and significance. This paper tabulates unpublished Sălcuta culture flint objects from a hoard found at Verbicioara, Dolj County in Romania. A series of comparisons with other Lower Danube similar discoveries is made to establish the possible significance of this discovery.
\end{abstract}

IZVLEČEK - V članku predstavljamo depo kamenih orodij kulture Sălcuţa, ki je bil najden na najdišču Verbicioara v okrožju Dolj v Romuniji. Depoji te vrste so vedno vzbujali zanimanje. Pri njihovem študiju je bila vedno v ospredju kontekstualnost, strukturiranost in pomen. Predstavljamo primerjave z drugimi podobnimi depoji ob Spodnji Donavi in mogoč pomen odkritja.

KEY WORDS - silex; hoard; Sălcuta culture; pit; Verbicioara

\section{Introduction}

During a reconsideration of the old collections at the National Museum of Antiquities (The Vasile Pârvan Institute of Archaeology of the Romanian Academy) a flint object hoard from Verbicioara settlement in Dolj County, Romania (Fig. 1) was found. Archaeological research in Verbicioara was carried out during four campaigns (1949, 1950, 1951 and 1957) by a team directed by Dumitru Berciu. The hoard consists of 36 items (Tab. 1). It is obvious that many of them come from the same core. Typologically, the following tools can be identified: 4 grattoirs (scrapers), 24 blades, 3 flakes, 3 blade-shaped flakes and 2 atypical flakes (Fig. 4).

The information on the hoard's context of discovery is imprecise. Dumitru Berciu, the Verbicioara excavations author, vaguely mentions the context of discovery in a short excavation report dedicated to the first archaeological investigations of this settlement. He specifies that the hoard was found 'in a pit bottom' of the Sălcuţa culture area (Berciu 1950. 104). The items are marked 'Section II, $-2.20 \mathrm{~m}$ '. Apart from these details we have no other information, such as the dimensions of the pit, the stratigra- phic level from which the complex was dug, or to which phase the Sălcuţa pit is attributable. When analysing such Lower Danube Eneolithic hoards and their context of discovery, it is noticeable that most of them (8) were discovered in pits (Fig. 2), while 8 come from the cultural layer, 6 were found inside vessels and 4 were discovered inside dwellings. Special reference can be made to three hoards found in Bulgaria in certain places: the one in a vessel found in the level IV sanctuary at Ruse, the one from Peklyuk - interpreted as a symbolic burial - and the one from Drama found in the enclosure ditch filling ( $A v$ ramova 2008.212-213; Lichardus, Lichardus-Itten 1993.18). 22 hoards contained exclusively flint artefacts, while 7 also had other types of item as well as the silex examples (Fig. 3). Doubtless, John Chapman's article is one of the most interesting studies on Neo-Eneolithic pits. According to Chapman (2000. 64) "[the] pit filling is, by definition, a metaphor for reincorporation of current material into a context defined by earlier deposits". Especially at tell type settlements, the digging of pits can be seen as mediating an exchange with the ancestors: the new material for the old, when the pit is dug into earlier 
cultural layers. One of the key concepts used by Chapman (2000.65) is 'structured deposition': the deliberate accumulation of varied materials, the association of which is rare, and the structuring of such association being unusual.

For a long time, it has been thought that pits are depositions of 'waste', but this twentieth-century concept has nothing to do with the prehistoric mentality. Approximately in the same way Mark Edmonds (1995.128) believes that the digging and filling of pits could have served in certain contexts "to reaffirm the links between particular people, their descendants, and specific places in the landscape". As mentioned above, 6 hoards were found in clay vessels. We find the pit-vessel analogy very clear: both are made of clay, on the one hand in a natural state, and on the other hand transformed by fire. Both are receptacles, but the vessel's advantage is its mobility: it can be carried to many places, inside or outside the settlement. The two substances merge at the moment the vessel is buried. The first returns to its creative substance, thus ending a cycle. 'Enchainment' is another key concept discussed by Chapman. When placing a fragmentary object/artefact inside a grave or pit, a relationship is established or strengthened between those persons connected by such special deposition and other persons in the living world/surrounding world (Chapman 2000.82).

\begin{tabular}{|c|c|c|c|c|}
\hline Tool & Colour & Max. lenght & Max. width & Reference \\
\hline 1. Grattoir & beige with white spots & $8 \mathrm{~cm}$ & $4 \mathrm{~cm}$ & (Figure 5a) \\
\hline 2. Grattoir & beige with white spots & $6.4 \mathrm{~cm}$ & $2.8 \mathrm{~cm}$ & (Figure 5b) \\
\hline 3. Grattoir & beige with white spots & $6.1 \mathrm{~cm}$ & $3 \mathrm{~cm}$ & (Figure 5c) \\
\hline 4. Grattoir & beige with white spots & $5.5 \mathrm{~cm}$ & $3 \mathrm{~cm}$ & (Figure 5d) \\
\hline 5. Blade & beige with white spots & $6.3 \mathrm{~cm}$ & $2.4 \mathrm{~cm}$ & (Figure 6a) \\
\hline 6. Blade & beige & $5.8 \mathrm{~cm}$ & $1.5 \mathrm{~cm}$ & (Figure 6b) \\
\hline 7. Blade & beige with white spots & $3.6 \mathrm{~cm}$ & $1.9 \mathrm{~cm}$ & (Figure 6c) \\
\hline 8. Blade & brown with white spots & $3.5 \mathrm{~cm}$ & $1.5 \mathrm{~cm}$ & (Figure 6d) \\
\hline 9. Blade & beige with white spots & $3.8 \mathrm{~cm}$ & $1.4 \mathrm{~cm}$ & (Figure 6e) \\
\hline 10. Blade & $\begin{array}{l}\text { brown with white spots, } \\
\text { retouched on both sides }\end{array}$ & $4.4 \mathrm{~cm}$ & $1.8 \mathrm{~cm}$ & (Figure 6f) \\
\hline 11. Blade & beige with white spots & $4.7 \mathrm{~cm}$ & $1.9 \mathrm{~cm}$ & (Figure 6g) \\
\hline 12. Blade & beige with white spots & $2.7 \mathrm{~cm}$ & $1.5 \mathrm{~cm}$ & (Figure 6h) \\
\hline 13. Blade & brown, translucent & $3 \mathrm{~cm}$ & $1.2 \mathrm{~cm}$ & (Figure 6i) \\
\hline 14. Blade & beige with white spots & $2.5 \mathrm{~cm}$ & $1.3 \mathrm{~cm}$ & (Figure 6j) \\
\hline 15. Blade & beige with white spots & $3.5 \mathrm{~cm}$ & $1.5 \mathrm{~cm}$ & (Figure 6k) \\
\hline 16. Blade & beige with white spots & $2.9 \mathrm{~cm}$ & $1.9 \mathrm{~cm}$ & (Figure 6I) \\
\hline 17. Blade & $\begin{array}{l}\text { brown with white spots } \\
\text { retouched on one side }\end{array}$ & $3.9 \mathrm{~cm}$ & $1.5 \mathrm{~cm}$ & (Figure $6 \mathrm{~m}$ ) \\
\hline 18. Blade & grey with white spots & $6.1 \mathrm{~cm}$ & $2.8 \mathrm{~cm}$ & (Figure 6n) \\
\hline 19. Blade & beige with white spots & $6.4 \mathrm{~cm}$ & $1.5 \mathrm{~cm}$ & (Figure 6o) \\
\hline 20. Blade & beige with white spots & $4 \mathrm{~cm}$ & $2 \mathrm{~cm}$ & (Figure 6p) \\
\hline 21. Blade & beige with white spots & $5.7 \mathrm{~cm}$ & $2.7 \mathrm{~cm}$ & (Figure 6q) \\
\hline 22. Blade & beige with white spots & $5.3 \mathrm{~cm}$ & $2.2 \mathrm{~cm}$ & (Figure 6r) \\
\hline 23. Blade & beige with white spots & $7 \mathrm{~cm}$ & $2 \mathrm{~cm}$ & (Figure 6s) \\
\hline 24. Blade & beige & $6.5 \mathrm{~cm}$ & $1.7 \mathrm{~cm}$ & (Figure 6t) \\
\hline 25. Blade & beige & $7.4 \mathrm{~cm}$ & $2.7 \mathrm{~cm}$ & (Figure 6u) \\
\hline 26. Blade & beige with white spots & $9.8 \mathrm{~cm}$ & $2.5 \mathrm{~cm}$ & (Figure 6v) \\
\hline 27. Blade & beige with white spots & $9.1 \mathrm{~cm}$ & $1.5 \mathrm{~cm}$ & (Figure 6w) \\
\hline 28. Blade & beige with white spots & $8.2 \mathrm{~cm}$ & $2.8 \mathrm{~cm}$ & (Figure 6x) \\
\hline 29. Flake & beige with white spots & $5.6 \mathrm{~cm}$ & $3 \mathrm{~cm}$ & (Figure 7a) \\
\hline 30. Flake & beige with white spots & $6.5 \mathrm{~cm}$ & $3.3 \mathrm{~cm}$ & (Figure $7 b$ ) \\
\hline 31. Flake & beige with white spots & $6.8 \mathrm{~cm}$ & $3.1 \mathrm{~cm}$ & (Figure 7c) \\
\hline 32. Blade-shaped flake & beige with white spots & $6.5 \mathrm{~cm}$ & $3.1 \mathrm{~cm}$ & (Figure 8a) \\
\hline 33. Blade-shaped flake & beige with white spots & $8.8 \mathrm{~cm}$ & $3.7 \mathrm{~cm}$ & (Figure 8b) \\
\hline 34. Blade-shaped flake & beige with white spots & $8.8 \mathrm{~cm}$ & $3.1 \mathrm{~cm}$ & (Figure 8c) \\
\hline 35. Atypical flake & brown with white spots & $3.3 \mathrm{~cm}$ & $1.2 \mathrm{~cm}$ & (Figure 9a) \\
\hline 36. Atypical flake & beige with white spots & $2.2 \mathrm{~cm}$ & $1.8 \mathrm{~cm}$ & (Figure gb) \\
\hline
\end{tabular}

Tab. 1. The contents and the description of the Verbicioara stone tool deposition. 
Two similar situations regarding hoards are discussed in this study: from Romania (Leşile) and Bulgaria (Peklyuk). Both consist of structured depositions of vessels (Nania 1965.311-321; Avramova 2008. 213) together with flint and stone items and also fragmentary anthropomorphic figurines. The idea that such situations can be interpreted as symbolic burials could gain more support if more examples of this type from the South-Eastern European Eneolithic had been found.

As noted above, the Balkan Eneolithic was a period when 'set accumulation' becomes very important. Compared to the Neolithic, the number, extent and diversity of sets strongly increase in Eneolithic, including five types of sets: costume sets, figurine scenes, burials, burnt dwellings and hoards. As of 2000, over 70 Balkan Neolithic and Eneolithic hoards with different compositions were known (Gaydarska et al. 2004.28).

Unfortunately, the excavation methods and low quality of the system of recording data from many Lower Danube sites is the main reason for the lack of detailed information which would allow a more precise analysis of such depositions. In many cases, archaeological complexes were not recorded in drawings or photographs, so we do not know the items' actual position, the pit structure or other data essential for a complete analysis. In those cases in which such data exists, interesting conclusions can be drawn; for example, that in some cases artefacts were selected in a particular way before being deposited without having a special arrangement. In other cases, items were positioned in a specific way; but

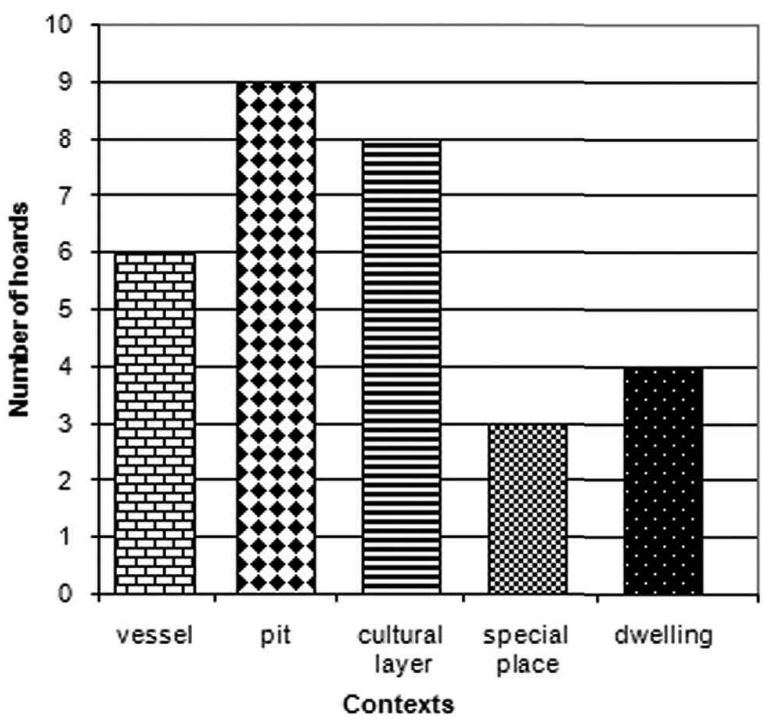

Fig. 2. The contexts of Chalcolithic flint hoards in the Lower Danube.

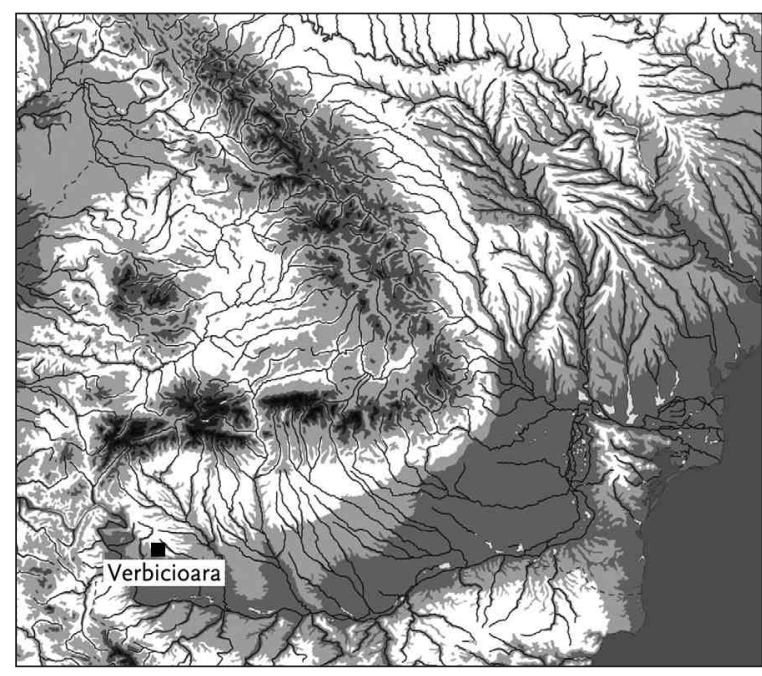

Fig. 1. The settlement of Verbicioara, Dolj County, Romania.

there are also cases in which the objects were simply thrown together, a situation improperly called the disposal of 'rubbish' (Garrow 2007.14) (Tab. 2).

Other authors have identified an 'aesthetics of deposition' in the British Neolithic. Therefore, artefact depositions in settlement enclosure ditches, as well as in pits, have been reported. Moreover, a refinement of these practices in Late Neolithic has been noticed in comparison with the early Neolithic period (the same as in the Balkans, see below). The depositions are composed of interesting 'fresh' and 'transformed' material: 'tool kit' style selection of flint implements, 'exotic' items such as foreign stone axes and marine shells, and unusual assemblages of wild and domesticated animal bone (Pollard 2001. 325). A conclusion which can be drawn is that the

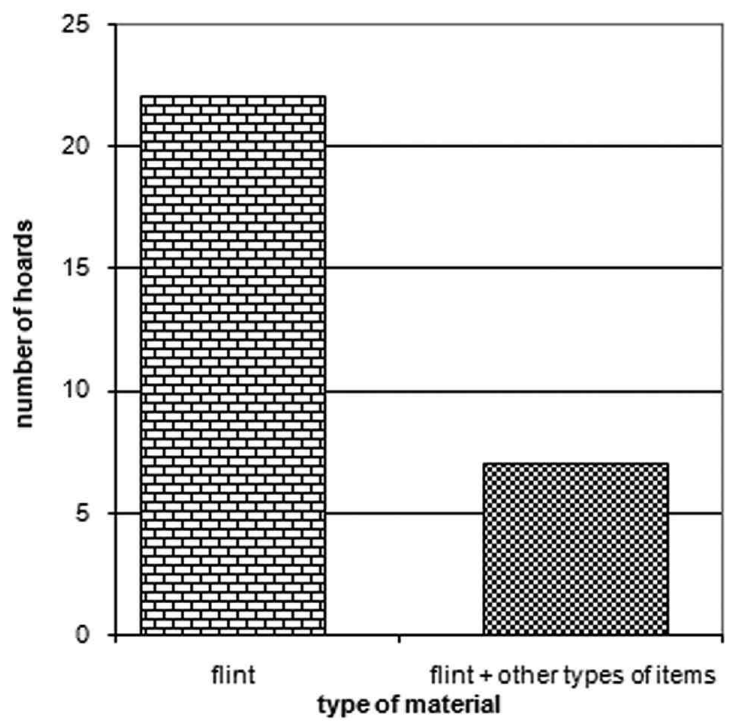

Fig. 3. The structure of Chalcolithic hoards in the Lower Danube. 
1. Aldeni - 'Gurguiul Balaurului', Romania: 9 silex blades and three (?) small plate axes; at the base of lower layer; Stoicani-Aldeni (Comşa 1963.13).

2. Ariuşd, Romania: 15 silex items, including a knife blade, a striker and a scraper; deposited in a vessel; CucuteniAriuşd (László 1911.257).

3. Băbăița, Romania: 16 complete and fragmentary blades; isolated find; Gumelniţa (Torcică 2011.133-142).

4. Bikovo - 'Deneva mogila', Bulgaria: a hoard consisting of 5 blades and 6 scrapers stemming from the same core; Karanovo VI (Lichardus, Lichradus-Itten 1993.18).

5. Brebeni, Romania: 20 flint blades; isolated find; Sălcuţa (Nania 1965.315, Note 6).

6. Bulgarene, Bulgaria: silex knife hoard; deposited in a vessel, about $7 \mathrm{~km} \mathrm{SW}$ of the village; Chalcolithic (Avramova 2008.212).

7. Cjakmaka, Bulgaria: at the tell-settlement some pits were investigated which contained cores, flakes and debitage from flint production; Chalcolithic (Avramova 2008.213).

8. Drama - 'Merdžumekja', Bulgaria: in the filling of 360/1 enclosure a hoard consisting of 3 blades and a scraper was found; Karanovo VI (Lichardus, Lichradus-Itten 1993.18).

9. Gumelniţa, Romania: 6 silex blades; cultural layer; Gumelniţa A2 (Dumitrescu 1966.57).

10. Hotnica, Bulgaria: 24 non-retouched items, without traces of use; in dwelling $\mathrm{N} 5$ from the $3^{\text {rd }}$ horizon; Gumelniţa-Karanovo VI (Avramova 2008.213).

11. Ipotești, Romania: flint tools and flakes, a small chisel and a fragmentary axe; pit; Vădastra I (Comşa 1962.217).

12. Karanovo, Bulgaria: hoard consisting of 7 blades with lengths between 4.4 and $15 \mathrm{~cm}$; cultural layer; Karanovo VI (Lichardus, Lichardus-Itten 1993.17).

13. Kosharna, Bulgaria: a hoard consisting of 23 flint artefacts, shells, Spondylus fragments, etc.; found in a jar during the 2009 campaign; Gumelniţa-Karanovo VI (Gurova 2011.180, 185).

14. Leşile, Romania: 18 blades, 9 scrapers, 7 spearheads and 5 arrowheads (all flint), 3 small chisels and 2 axes (stone), a fragmentary anthropomorphic figurine; isolated find; the items were deposited in a vessel; Gumelniţa B1 (Nania 1965.311-310).

15. Lîga, Bulgaria: hoard consisting of 9 blades stemming from the same core; found near an oven in House 3; Sălcuţa-Krivodol (Albek 2005.114-115).

16. Omurtag, Bulgaria: 11 fragments of Spondylus bracelets, 8 small Spondylus fragments, a Cardium shell, a broken perforated bone pendant, 1 polished stone bead, 2 bone plates, 3 pig incisors, 2 flint proximal blade segments, a piece of pumice (imported), 1 trapezoidal miniature polished stone axe and 2 quartzite polishing pebbles (smoothers); in a vessel; Chalcolithic (Gaydarska et al. 2004.11-34; Avramova 2008.213).

17. Ostrovul Corbului, Romania: 15 silex items; cultural layer; Sălcuţa (Вerciu 1939.62).

18. Peklyuk, Bulgaria: 6 silex knives associated with other items discovered in a circular feature interpreted as a symbolic burial; Late Chalcolithic (Avramova 2008.213).

19. Piatra Şoimului (Calu), Romania: 12 flint axes and chisels on the slope of a hill; Cucuteni A (Mătasă 1959.729).

20. Pietrele - 'Gorgana', Romania: 11 flint blades; near a hearth; Gumelniţa A1 (Веrciu 1956.505).

21. Radovanu, Romania: a hoard found between dwellings B and C of the second settlement which contained 10 medium size flint blades; another hoard of the same settlement was found in a small pit, near dwelling 1 , and contained 50 blades detached from the same core; Boian-Spanţov (Comşa 1990.30).

22. Ruse, Bulgaria: in the tell-settlement, 4 flint hoards were discovered at various depths -1 was found at $2.20 \mathrm{~m}$ which contained 15 long curve knives with traces of use; the second was found at $3.70 \mathrm{~m}$ and contained 24 silex knives without traces of use; the third was found in dwelling $\mathrm{N} 2$, at $4.70 \mathrm{~m}$ depth, and contained 30 flint knives and scrapers; the fourth was discovered in a vessel from the sanctuary belonging to the settlement's fourth level; Gumelniţa-Karanovo VI (Avramova 2008.212-213).

23. Sălcuţa - 'Piscul Cornişorului', Romania: 4 microlithic tools, 2 or 3 fragmentary knives, an arrowhead, few splints, a core; in 'pit a' from trench I; Sălcuţa I (Веrciu 1961.195, 198).

24. Smyadovo, Bulgaria: 59 stone items (axes, scrapers, knives and blades, without traces of use); on the floor of a destroyed house; Gumelniţa-Karanovo VI (Avramova 2008.213).

25. Valea Adâncă-'Dealul Nucului', Romania: 5 flint axes and a fragmentary core; in a pit; Cucuteni A-B (Florescu 1960.215-222).

26. Verbicioara - 'La Trestii', Romania: 36 flint items: four grattoirs, 24 blades, 3 flakes, 3 blade shaped flakes and 2 atypical flakes; in a pit; Sălcuţa.

Tab. 2. The stone tool depositions in Neolithic and Eneolithic settlement contexts in Lower Danube. 
object/person dichotomy is false and must be overcome in order to understand "how the agency of things structures the way people deal with them" (Pollard 2001.330).

A different non-ritual explanation for flint object deposition in pits could be their preservation for the purpose of being processed more easily in a subsequent phase. This could also explain why such discoveries are rare in certain areas in Europe - after a while the items were taken from the pit and processed or used as such (Saville 1999.108).

As mentioned above, the 36 items in our hoard are of different types of silex (at least 3). Their deposition can be related to a commemorative act, or an act to commemorate the memory of the identity of the Verbicioara Sălcuţa community (Pauketat, Alt. 794). The interpretation of these hoards can be related to ritual meanings; probably potlatch-type rituals (Mauss 1993.40-44).

Three structured types of deposition can be observed in the stone tool hoards from Cucuteni, Gumelniţa-Karanovo VI and Sălcuţa-Krivodol cultural areas (Mircea, Pandrea 1997.180):

(1) hoards comprised exclusively of flaked silex tools and flint blades, which only appear in settlements;

(2) hoards comprised of flint blade-shaped tools and polished stone axes, which appear in settlements and outside settlements;

(3) hoards encountered only outside settlements consisting exclusively of polished stone axes.

Until $19^{\text {th }}$ century, Neolithic stone axes were considered as 'thunderbolts'. Their actual function was established after ethnographic comparisons (Neustupný 1971.37). Mircea Eliade (1992.89) expresses a very interesting point of view when describing a Roman ritual: "The oak was reserved for Jupiter (as for Zeus) being the most frequently thunderstruck tree. The Capitol oak tree belonged to Jupiter Feretrius, qui ferit, he who strikes, also named Jupiter Lapis, who was represented by a silex. Like all gods, Jupiter punished with lightning thunder strikes bolts; above all, he punished people who broke their word, or who violated a treaty. Jupiter Lapis consecrated internatio-
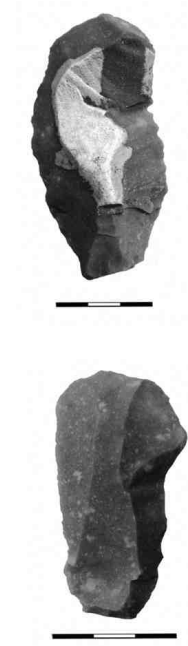

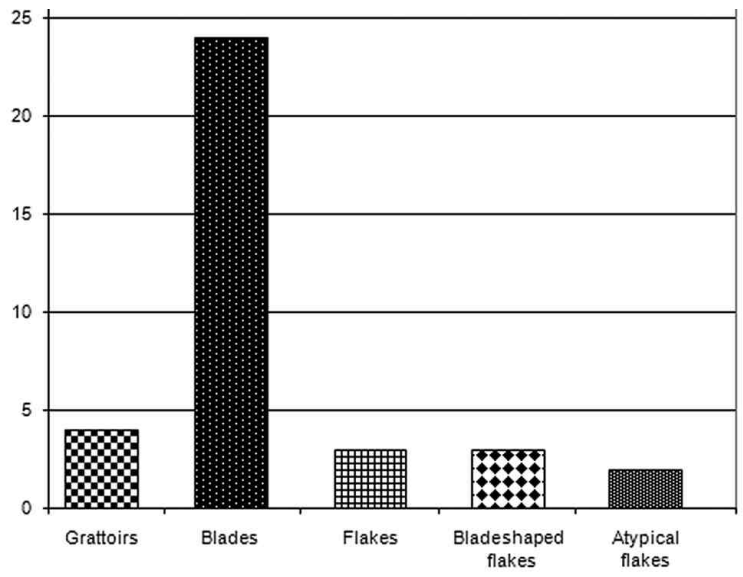

Fig. 4. Types of flint items of the hoard from Verbicioara, Romania.

nal treaties; a special priest sacrificed a pig with a sacred silex, proclaiming: "If the Roman people violate the treaty, may Jupiter strike them, as I am striking now this pig with the stone."' (see also Avramova 2008.212).

Why silex? Probably because striking it produces sparks, and therefore fire (smaller, more controllable lightning). For Central American Indians, silex, which in ancient times was used in sacrifices, kept its magic value, that of removing charms and evil spirits. In Mexico, flint is worshiped, being considered the son of the primordial goddess couple who attended every creation. An interesting practice which illustrates two opposed functional associations of the same symbol is encountered in the Aztec case: healing wounds were covered with an ointment containing flint powder - flint has the power both to open and close human tissue (Chevalier, Gheerbrant 1993.228-229).
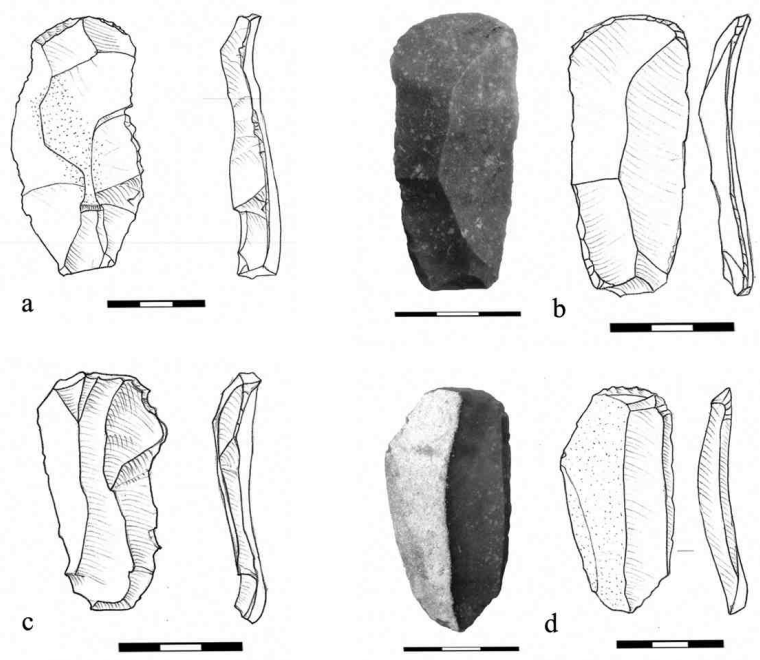

Fig. 5. Grattoirs (scrapers) from the Verbicioara hoard (photo and drawings Cristina Georgescu). 

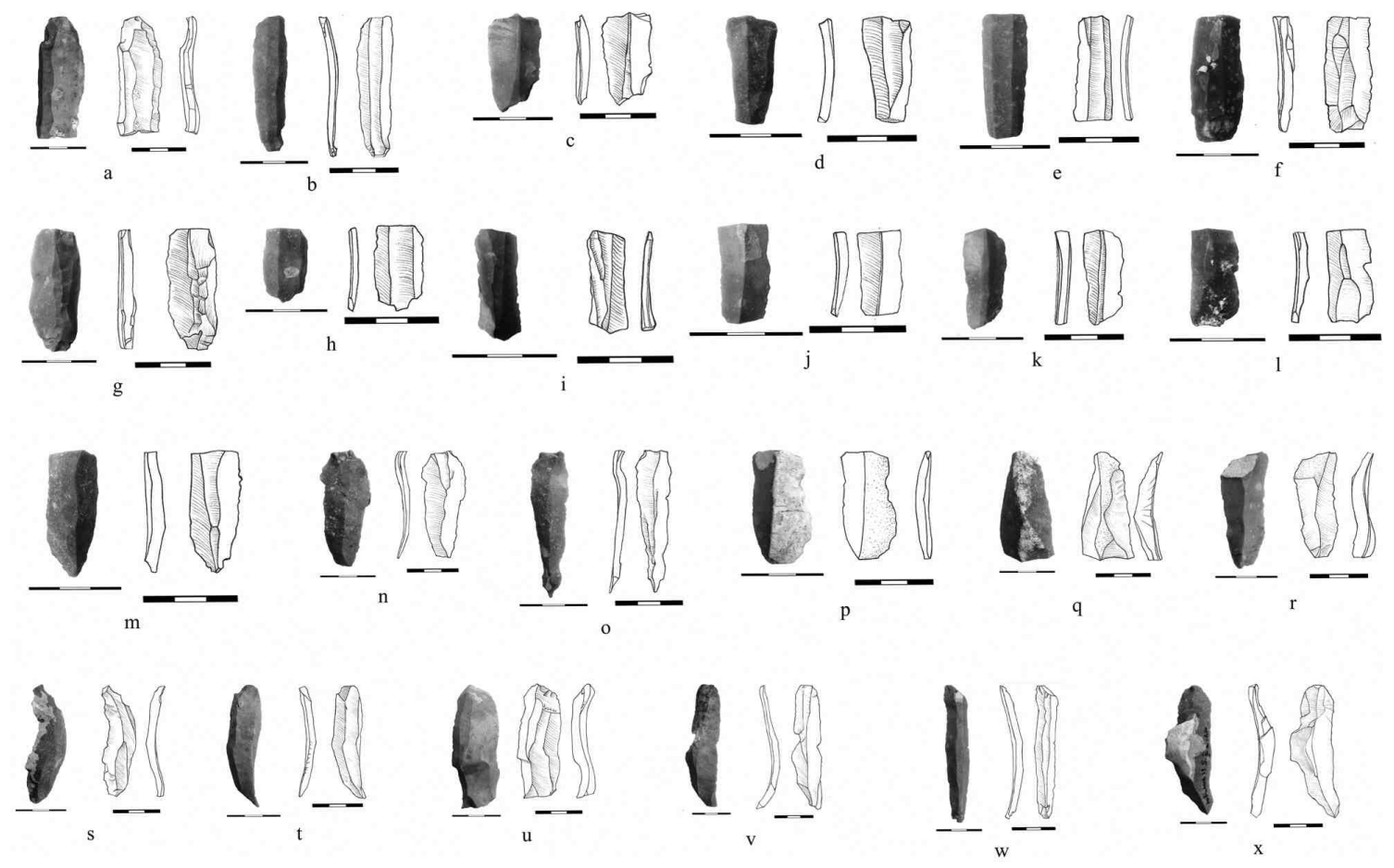

Fig. 6. Blades from the Verbicioara hoard (photo and drawings Cristina Georgescu).
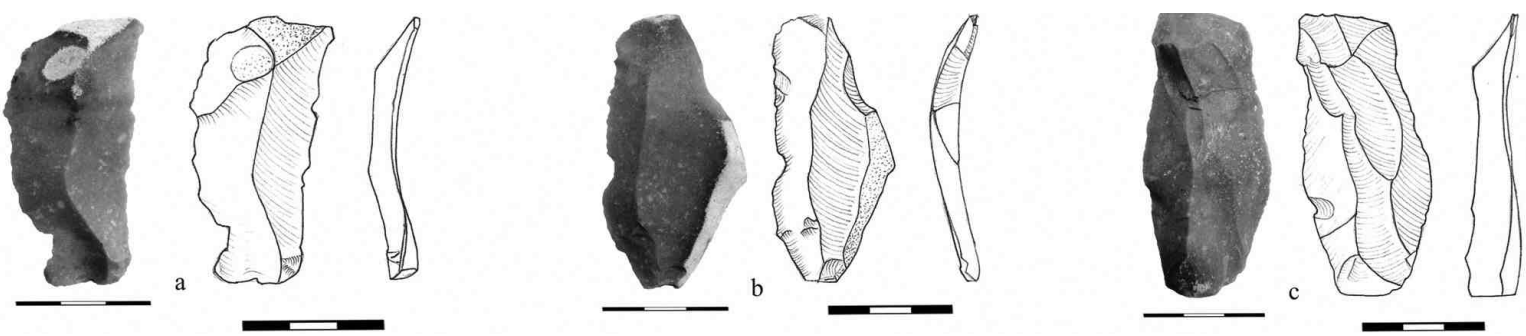

Fig. 7. Flakes from the Verbicioara hoard (photo and drawings Cristina Georgescu).
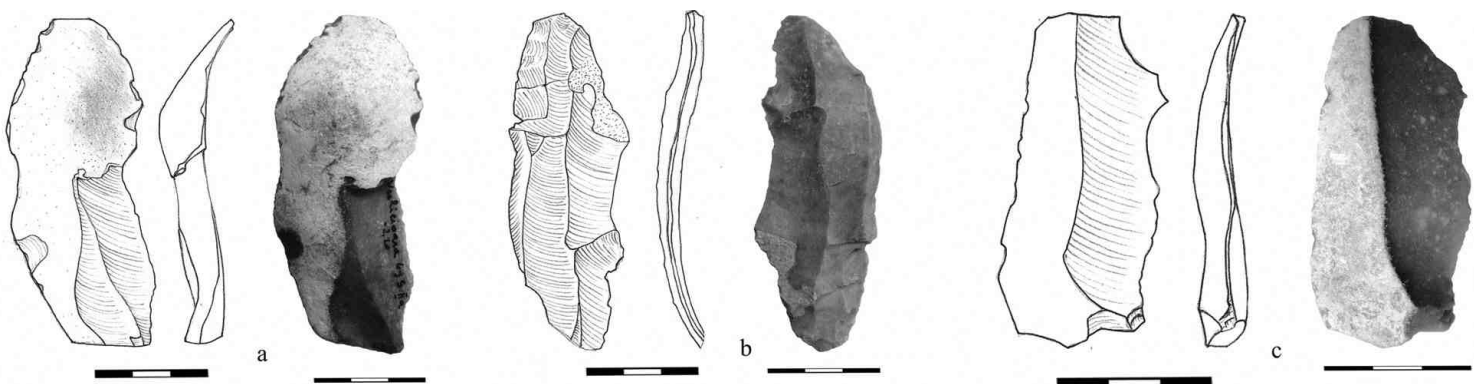

Fig. 8. Blade-shaped flakes from the Verbicioara hoard (photo and drawings Cristina Georgescu).
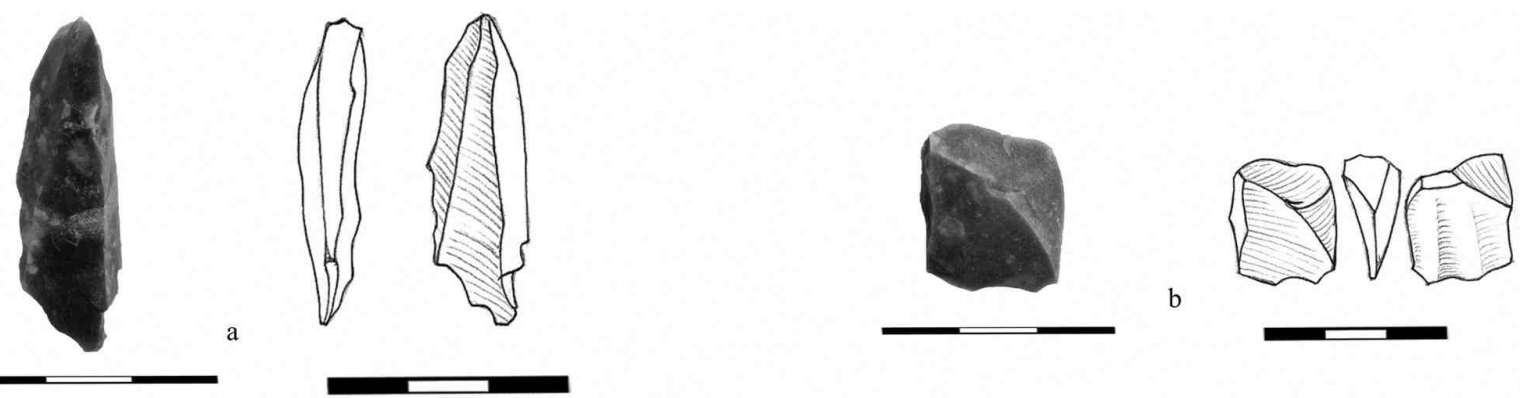

Fig. 9. Atypical flakes from the Verbicioara hoard (photo and drawings Cristina Georgescu). 


\section{References}

Albek S. 2005. Stone tools. In K. Randsborg (ed.), Lîga. Copper Age strategies in Bulgaria. Acta Archaeologica 76 (1), Suppl. 6. Centre of World Archaeology, Publ. 2, Oxford: $112-116$.

Avramova M. 2008. 'Special' stones in prehistoric practices: cases from Bulgaria. In R. I. Kostov, B. Gaydarska and M. Gurova (eds.), Geoarchaeology and Archaeominera$\log y$. Proceedings of the International Conference, 29-30 October 2008 Sofia, Publishing House 'St. Ivan Rilski', Sofia: 211-215.

Berciu D. 1939. Arheologia preistorică a Olteniei. Arhivele Olteniei XVIII: 1-90.

1950. Santierul arheologic dela Verbicioara-Dolj. Studii şi cercetări de istorie veche I (1-2): 103-107.

1956. Cercetări şi descoperiri arheologice în regiunea Bucureşti. Materiale şi Cercetări Arheologice II: 493562.

1961. Contributii la problemele neoliticului în România în lumina noilor cercetări. București.

Chapman J. 2000. Pit-digging and Structured Deposition in the Neolithic and Copper Age. Proceedings of the Prehistoric Society 66: 61-87.

Chevalier J., Gheerbrant A. 1993. Dictionar de simboluri. Vol. 3. P-Z. Ed. Artemis. Bucureşti.

Comşa E. 1962. Săpături arheologice la Ipotești. Materiale şi Cercetări Arheologice VIII: 213-219.

1963. Unele probleme ale aspectului cultural Aldeni II (Pe baza săpăturilor de la Drăgănești-Tecuci). Studii şi cercetări de istorie veche XIV(1): 7-31.

1990. Complexul neolitic de la Radovanu. Cultură şi civilizatie la Dunărea de Jos VIII: 5-126.

Dumitrescu V. 1966. Gumelniţa. Sondajul stratigrafic din 1960. Studii si cercetări de istorie veche XVII (1): 51-99.

Edmonds M. 1995. Stone Tools and Society. Working Stone in Neolithic and Bronze Age Britain. Routledge. London and New York.

Eliade M. 1992. Tratat de istorie a religiilor. Humanitas. Bucureşti.

Florescu A. C. 1960. Depozitul de unelte neolitice de la Valea Adâncă. Omagiu lui Constantin Daicoviciu. Bucureşti.
Gaydarska B., Chapman J. C., Angelova I., Gurova M. and Yanev S. 2004. Breaking, making and trading: the Omurtag eneolithic Spondylus hoard. Archaeologia Bulgarica VIII(2): 11-34.

Garrow D. 2007. Placing pits: Landscape Occupation and Depositional Practice During the Neolithic in East Anglia. Proceedings of the Prehistoric Society 73: 1-24.

Gurova M. 2011. A Late Chalcolithic Flint Assemblage from the Site of Kosharna, Russe District. In S. Mills, P. Mirea (eds.), The Lower Danube in Prehistory: Landscape Changes and Human-Environment Interactions. Proceedings of the International Conference, Alexandria, 3-5 november 2010, Bucureşti: 179-195.

Lázló F. 1911. Hármoszék vármegyei praemykenaei jellegű telepek. Dolgozatok II: 175-259.

Lichardus J., Lichardus-Itten M. 1993. Das Grab von Reka Devnja (Nordostbulgarien). Ein Beitrag zu den Beziehungen zwischen Nord- und Westpontikum in der frühen Kupferzeit. Saarbrücker Studien und Materialen zur Altertumskunde 2: 9-100.

Mauss M. 1993. Eseu despre dar. Institutul European. Iaşi.

Mătasă C. 1959. Descoperiri arheologice în raionul Piatra Neamţ. Materiale şi Cercetări Arheologice V: 723-734.

Mircea N., Pandrea S. 1997. »Depozitul« de topoare din piatră eneolitice de la Ghidigeni, jud. Galaţi. Istros VIII: 173190.

Nania I. 1965. Două depozite de unelte neolitice descoperite în raionul Costeşti (regiunea Argeş). Studii şi cercetări de istorie veche XVI(2): 311-321.

Neustupný E. 1971. Whither archaeology? Antiquity 45: 34-39.

Pauketat T. R., Alt S. M. 2004. The making and meaning of a Mississippian axe-head cache. Antiquity 78(302): 779-797.

Pollard J. 2001. The Aesthetics of Depositional Practice. World Archaeology 33(2): 315-333.

Saville A. 1999. A Cache of Flint Axeheads and Other Flint Artefacts from Auchenhoan, near Campbeltown, Kintyre, Scotland. Proceedings of Prehistoric Society 65: 83-123.

Torcică I. 2011. Depozitul de lame din silex descoperit în localitatea Băbăiţa (jud. Teleorman). Buletinul Muzeului Județean Teleorman 3: 133-142. 